\title{
Exploring the Relationship between Perceived Value and Intention to Purchase in Hotel Restaurants
}

\author{
Chieh-Heng Ko \\ Department of Hospitality Management, College of Tourism and Hospitality, Da-Yeh University, Chunghua, Taiwan \\ Email: chko@mail.dyu.edu.tw
}

How to cite this paper: Ko. C.-H. (2019) Exploring the Relationship between Perceived Value and Intention to Purchase in Hotel Restaurants. Open Access Library Journal, 6: e5108.

https://doi.org/10.4236/oalib.1105108

Received: December 12, 2018

Accepted: January 13, 2019

Published: January 16, 2019

Copyright () 2019 by author(s) and Open Access Library Inc.

This work is licensed under the Creative Commons Attribution International License (CC BY 4.0).

http://creativecommons.org/licenses/by/4.0/

\section{(c) (i) Open Access}

\begin{abstract}
Restaurants affiliated with the hotel industry play an important role in increasing revenue and responding effectively to customer expectations. This paper examines how perceived value relates to intention to purchase (ITP) in the context of hotel restaurant dining using a quantitative approach involving multiple regression analysis. In addition, the findings indicate that there are three significant key variables that positively contribute to ITP: perceived brand image, perceived quality and perceived sacrifice (both monetary and non-monetary price).
\end{abstract}

Subject Areas

Economics, Marketing

Keywords

Perceived Value, Intention to Purchase, Hotel Restaurant Dining

\section{Introduction}

Restaurant dining can provide a competitive advantage for hotels by more effectively meeting the needs of visitors and guests, and also providing a second income stream in addition to accommodation [1]. In turn, it is necessary for hotel managers to understand consumer expectations to ensure that they provide a product and service mix, which meets customer needs. This paper seeks to understand how perceived value in a hotel restaurant dining context relates to intention to purchase (ITP).

The study of restaurant dining has been a focus of research in recent years and includes the work of Heung and Lam [2], Weiss et al. [3] and Liu and Jang [4]. 
Heung and Lam [2] have examined customer complaint behavior in terms of hotel restaurant services, with their results showing a significant relationship between complaints and the socio-demographic problem of visitors, particularly age group and level of education. Weiss et al. [3] investigated four attributes of the restaurant experience: food quality, service quality, atmosphere and novelty, and their influence on repeat ITP. This study revealed that restaurant food quality and atmosphere remained the most important attributes relating to repeating intention. A study by Liu and Jang [4] found relationships between dining atmospherics, emotional response, perceived value and behavioral intention in a Chinese restaurant in the United States, and that perceived value significantly influenced consumers' post-dining behavioral ITP.

While these investigations provided valuable insights into consumer perceptions and restaurant dining more generally, research had not focused on the specific relationship between perceived value and ITP in hotel restaurant dining. Given the absence of work in this area this study is significant both academically as well as practically in terms of better design of marketing strategies, and in achieving an understanding of what consumers need and expect when it comes to the hotel restaurant.

This study utilized a quantitative methodology based on a convenience sample of guests staying at the Grand Hyatt Hotel in Taipei Taiwan, and was conducted between the months of June and August 2018. Using multiple regression techniques the study empirically examines how perceived value relates to ITP in this hotel restaurant dining context.

\section{Literature Review}

Perceived value assists in creating competitive advantage, as consumers will only purchase products or services they value. As such, Olshavsky [5] notes that an important key to understanding a consumer's perceived value of a brand is to determine a reason for purchase. In marketing, value is assessed from a consumer's perspective, and is the key link between the cognitive elements of perceived quality or performance, perceived monetary sacrifice and behavioral intentions [6]. Perceived quality is tied to both performance and perceived sacrifice [6]. In this way, value has a multidimensional character which includes quality perception, price perception, brand loyalty, familiarity and perceived risk [7] [8]. Incorporating the many conceptualizations of perceived value engaging with quality, price and benefit, this study uses the definition of consumer's overall evaluation of the utility of the product based on the perception of what is received and what is given [9]. As the perceived value of a product is a predictor of a customer's decision to purchase or not to purchase [10], the following section discusses each component of the perceived value construct.

\subsection{Perceived Brand Image}

Brand image is defined by Newman [11] as everything people associate with a 
brand. Importantly, brand image is a perceptual phenomenon formed through consumer interpretation, whether reasoned or emotional [12], and often used to express a consumer's interpretation of both the actual intrinsic as well as extrinsic characteristics of a product [13]. While extrinsic cues include product attributes, intrinsic cues include brand name, familiarity, manufacturer's reputation, and the popularity of brand and image or the theme of a brand [14]. Perceived brand image is affected by the information consumers receive from a store's name, for instance price and special promotions: these have been used to attract consumer perceptions and increase the level of brand image [15]. Likewise, the evaluation of a brand alliance relies on a consumer's experience with a brand, and opinions formed on the basis of several factors including the level of service experience, the price paid, and/or word of mouth [16].

In summary brand image is forged through consumer attitudes toward, and involvement with, a physical product, and/or how familiar the consumer is with the brand [17]. This strongly suggests that the perception of a brand's image influences consumer perception of its value, leading in turn to consumer ITP or otherwise [15]. This concept forms the basis of the first hypothesis in this investigation:

Hypothesis 1: If perceived brand image is high then intention to purchase is high.

\subsection{Perceived Quality}

Perceived quality is often defined as the perceived ability of a product to provide satisfaction relative to the available alternatives [18]. More broadly, perceived quality can be defined as the customer's perception of the overall quality or superiority of a product or service with respect to its intended purpose, relative to alternatives [19]. Moreover, Paswan et al. [16] assert that the main influence on perceived quality is the service element associated with it, with McDougall [20] similarly supporting the implication that the relationship between quality and value depends on overall service quality and improvement in core quality. Moreover, Zeithaml [17] found the relationship between quality and purchase also affects perceived value. For example, if product cost or service quality is too high and consumers are unwilling to pay for it, its value will not be perceived. Alternatively, if a purchase is of lower quality it may still satisfy if the price is commensurately affordable (which compensates for higher value) resulting in perception of value among consumers [17]. The second hypothesis in this investigation asserted that:

Hypothesis 2: If perceived quality is high then intention to purchase is high.

\subsection{Perceived Sacrifice}

Perceived sacrifice is also a determinant of perceived value [21], representing a trade-off between the qualities or benefits consumers perceive in a product and the price they have to pay for it. This price can include both a monetary (per- 
ceived price) component, and a non-monetary one such as time or energy spent [21]. Price plays a vital role determining perceived value, with the focus on what consumers are required to give to obtain something else [6] [18]. Likewise, price is representative of both product quality and value when it comes to a consumer's decision to purchase [18]. At its core, Monroe [22] defined price as the amount of money a consumer needs to sacrifice to acquire something they have aspirations for, with price contributing to perceived value and influencing consumer decision making [10] [18]. In summary, Monroe and Krishnan [18] consider price broadly according to two roles; firstly, it is a tool for determining what is to be sacrificed to obtain something; and secondly, as key to the perception of product quality, or as a signal of the qualities intrinsic to the product [18] [22]. This leads to the third and fourth hypotheses concerning this investigation:

Hypothesis 3: If perceived sacrifice on monetary price is low then intention to purchase is high.

Hypothesis 4: If perceived sacrifice on non-monetary price is low then intention to purchase is high.

\section{Methodology}

The measurement scale for the perceived value and ITP constructs in this study were adapted from the work of Dodds et al. [21] and Grewal et al. [15]. The perceived value construct is composed of three components; perceived brand image, perceived quality and perceived sacrifice (monetary price and non-monetary price).

Firstly, perceived brand image is measured using items examining salient intrinsic cues: the degree of consumer involvement with physical products' features (service and setting); and how familiar consumers are with the product (positive association and brand). The second category measures perceived quality, or the buyer's estimate of a product's importance based on extrinsic cues including reliability and quality of food. The third category measures perceived sacrifice based on both monetary price and non-monetary price. Pricing is indicative of the amount of monetary sacrifice needed for a purchase and provides an indication of the level of quality and perceived value [17]. Non-monetary prices, for example time and energy, are sacrificed by consumers to obtain products and services [17] [21]. Lastly, the research instrument scales used to measure ITP (the dependent variable) were developed from a scale proposed by Wells [23] and Axelrod [24].

A pilot test was conducted at a five star hotel located outside the center of Taipei, Taiwan. Both the pilot and the main study hotels are were part of the same chain and contained the same branded restaurant, as discussed below. All survey interviewing was conducted between 10:00 and 17:00 each day, in the common hotel areas of the lobby, open bar and swimming pool. Once guests had been approached and agreed to participate, they were provided with the menu, including meal, prices, as well as photos of the Henry J. Bean Bar and Grill res- 
taurant. This is a well-known restaurant from the United Kingdom and presents an all-American style bar and grill, famous for well-made drinks, cocktails and food served from the open grill. With its Tex Mex style dishes, it provides an unusual dining style within Asia. One unique feature is that from time to time all the staff (both waiters and chefs) will get together and dance in the restaurant. A total of 88 questionnaires were collected for the pilot test and the data entered into the SPSS. Analysis indicated that the scales for perceived brand image, perceived quality and perceived sacrifice based on monetary price variables were reliable (value $>0.75$ ). However, perceived sacrifice based on the non-monetary price variable had scale reliability just below the acceptable value (value $=0.72$ ). Subsequently, the wording was changed, resulting in a suitable Cronbach $\alpha$ 's $(=0.85)$ in the final survey. Lastly, the ITP variable measurement scale was reliable with $=0.84$.

\section{Results}

The key objective of this investigation was to answer the question: What is the relationship between perceived value and ITP in hotel restaurant dining? To this end, perceived value was seen to comprise of three core elements: perceived brand image, perceived quality and perceived sacrifice. These elements provided the basis for developing a number of hypotheses, and the results of each of these tested hypotheses will be presented below.

Hypothesis 1: If perceived brand image is high then intention to purchase is high.

The multiple regression technique was used to test Hypothesis 1. The ITP variable was created from a three-item seven-point Likert scale by accumulating the score of each item, the scale being reliable $=0.874, n=290$. The perceived brand image variable was created from a five-item seven-point Likert scale by accumulating the score of each item, the scale being reliable $=0.774, n=344$. The multiple regression analysis results are shown in Table 1. A total of 19.3 per cent of the variance in ITP was explained by the perceived brand image $\left(R^{2}=\right.$ $0.193, F(1271)=64.670, P<0.001)$. This showed a positive and significant relationship between the ITP and perceived brand image $(=0.439, t=8.042, P<$ $0.001)$.

Table 1. Perceived brand image regression results.

\begin{tabular}{|c|c|c|c|c|c|c|}
\hline \multirow{2}{*}{ Model } & \multicolumn{2}{|c|}{$\begin{array}{l}\text { Unstandardized } \\
\text { coefficients }\end{array}$} & \multirow{2}{*}{$\begin{array}{c}\text { Standardized } \\
\text { coefficients } \\
\text { Beta }(\beta)\end{array}$} & \multirow{2}{*}{$\mathrm{t}$} & \multirow{2}{*}{ Sig. } & \multirow{2}{*}{$\mathrm{F}$} \\
\hline & B & $\begin{array}{l}\text { Std. } \\
\text { error }\end{array}$ & & & & \\
\hline (Constant) & -2.278 & 1.683 & - & -1.354 & 0.177 & $\begin{array}{c}64.670 \\
(1271)^{\star * \star}\end{array}$ \\
\hline $\begin{array}{c}\text { Perceived } \\
\text { brand image }\end{array}$ & 0.628 & 0.078 & 0.439 & 8.042 & 0.000 & - \\
\hline
\end{tabular}

Dependent variable: Intention to purchase, $R^{2}=0.193 .{ }^{* *} P<0.001$. 
In summary, it was hypothesized that if perceived brand image is high then ITP is high. The findings suggested that perceived brand image explains approximately 20 per cent of the variance; as a consequence Hypothesis 1 was supported.

Hypothesis 2: If perceived quality is high then intention to purchase is high.

The multiple regression technique was used to test Hypothesis 2. The ITP variable used the same measurement scale as in Hypothesis 1. The perceived quality variable was created from a three-item seven-point Likert scale by accumulating the score of each item, the scale being reliable $=0.831, n=353$. The results are shown in Table 2 . A total of 13.8 per cent of the variance in ITP $\left(R^{2}=0.138\right.$, $F(1279)=44.667, P<0.001)$ was explained by the perceived quality. There was a positive and significant relationship between perceived quality and ITP $(=0.371$, $t=6.683, P<0.001)$.

In summary, it was hypothesized that if perceived quality is high then ITP is high. It was found that perceived quality was positively associated with consumer intention to purchase, and explained approximately 14 per cent of the variance; as a consequence Hypothesis 2 was supported.

Hypothesis 3: If perceived sacrifice on monetary price is low then intention to purchase is high.

The multiple regression technique was used to test Hypothesis 3. The ITP variable used the same measurement scale as in Hypotheses 1 and 2. The perceived sacrifice on the monetary price variable was created from a two-item seven-point Likert scale by accumulating the score from each item, the scale being reliable with alpha value $=0.984, n=364$. The results are shown in Table 3 . A total of

Table 2. Perceived quality regression results.

\begin{tabular}{|c|c|c|c|c|c|c|}
\hline \multirow[t]{2}{*}{ Model } & \multicolumn{2}{|c|}{$\begin{array}{l}\text { Unstandardized } \\
\text { coefficients }\end{array}$} & \multirow{2}{*}{$\begin{array}{c}\text { Standardized } \\
\text { coefficients } \\
\text { Beta }(\beta)\end{array}$} & \multirow[t]{2}{*}{$\mathrm{t}$} & \multirow{2}{*}{ Sig. } & \multirow[t]{2}{*}{$\mathrm{F}$} \\
\hline & B & Std. error & & & & \\
\hline (Constant) & -1.713 & 1.903 & - & -0.888 & 0.376 & $\begin{array}{c}44.667 \\
(1279)^{* * *}\end{array}$ \\
\hline $\begin{array}{c}\text { Perceived } \\
\text { brand image }\end{array}$ & 0.628 & 0.078 & 0.439 & 8.042 & 0.000 & - \\
\hline
\end{tabular}

Dependent variable: Intention to purchase, $R^{2}=0.138$. ${ }^{* *} P<0.001$.

Table 3. Monetary price regression results.

\begin{tabular}{ccccccc}
\hline \multirow{2}{*}{ Model } & \multicolumn{2}{c}{$\begin{array}{c}\text { Unstandardized } \\
\text { coefficients }\end{array}$} & $\begin{array}{c}\text { Standardized } \\
\text { coefficients }\end{array}$ & t & Sig. & F \\
\cline { 2 - 4 } (Constant) & 2.900 & 1.264 & - & 2.294 & 0.023 & $\begin{array}{c}43.318 \\
(1287)^{* * *}\end{array}$ \\
$\begin{array}{c}\text { Perceived sacrifice } \\
\text { on monetary price }\end{array}$ & 1.032 & 0.157 & 0.362 & 6.582 & 0.000 & - \\
\hline
\end{tabular}

Dependent variable: Intention to purchase, $R^{2}=0.131 .{ }^{* * *} P<0.001$. 
13 per cent of the variance in ITP $\left(R^{2}=0.131, F(1287)=43.318, P<0.001\right)$ was explained by perceived sacrifice (monetary price 0 . There was a positive and significant relationship between the ITP and perceived sacrifice on monetary price (=0.362, $t=6.582, P<0.001)$.

In summary, it was hypothesized that if perceived sacrifice on monetary price is low then ITP is high. The findings suggest that perceived sacrifice on monetary price positively predicted intention to purchase, and explained approximately 13 per cent of the variance; as a consequence Hypothesis 3 was supported.

Hypothesis 4: If perceived sacrifice on non-monetary price is low then intention to purchase high.

The multiple regression technique was conducted to test Hypothesis 4 . The ITP variable used the same measurement scale as the previous hypotheses. The perceived sacrifice on the non-monetary price variable was created from a three-item seven-point Likert scale by accumulating the score from each item, the scale being reliable with alpha value $=0.851, n=361$. The results are shown in Table 4. A total of 21.7 per cent of the variance in ITP $\left(R^{2}=0.217, F(1284)=\right.$ 78.831, $P<0.001)$ was explained by perceived sacrifice (non-monetary price). There was a positive and significant relationship between the ITP and perceived sacrifice (non-monetary price) $(=0.466, t=8.879, P<0.001)$.

In conclusion, it was hypothesized that if perceived sacrifice on non-monetary price is low then ITP is high. The findings suggested that perceived sacrifice on non-monetary price was positively related to ITP, and explained approximately 20 per cent of the variance; as a consequence Hypothesis 4 was supported.

\section{Discussion and Conclusions}

To investigate the relationship between perceived value and ITP in a hotel restaurant dining context this investigation examines the question: What is the relationship between perceived value and ITP? Four hypotheses were developed and statistical analysis performed using multiple regression technique.

The results support Hypothesis 1, with brand image being positively related to ITP in a hotel restaurant dining context. The perceived brand image component explained almost 20 per cent of the variance in ITP. This supports previous

Table 4. Non-monetary price regression results.

\begin{tabular}{|c|c|c|c|c|c|c|}
\hline \multirow{2}{*}{ Model } & \multicolumn{2}{|c|}{$\begin{array}{l}\text { Unstandardized } \\
\text { coefficients }\end{array}$} & \multirow{2}{*}{$\begin{array}{c}\begin{array}{c}\text { Standardized } \\
\text { coefficients }\end{array} \\
\text { Beta }(\beta)\end{array}$} & \multirow[t]{2}{*}{$\mathrm{t}$} & \multirow{2}{*}{ Sig. } & \multirow[t]{2}{*}{$\mathrm{F}$} \\
\hline & B & Std. error & & & & \\
\hline (Constant) & 5.566 & 1.889 & - & -2.947 & 0.003 & $\begin{array}{c}78.831 \\
(1284)^{\star * *}\end{array}$ \\
\hline $\begin{array}{c}\text { Perceived sacrifice } \\
\text { on non-monetary } \\
\text { price }\end{array}$ & 1.302 & 0.147 & 0.466 & 8.879 & 0.000 & - \\
\hline
\end{tabular}

Dependent variable: Intention to purchase, $R^{2}=0.217$. ${ }^{* *} P<0.001$. 
literature, as Zeithaml [17] and Simonin and Ruth [25] also found that perceived brand image is tied to product image, in that consumers are familiar with, for example, the product attributes. In addition, this also involves the degree to which a consumer recognizes, or does not recognize the brand [17] [25]. In this way, consumer perceptions of brand image develop from the recommendations of friends or family, or from information from several sources such as media or company direct sales [5] [17]. The results of this analysis clearly confirm that the effect of brand image is focused on, and concerned with a consumer's attitude toward and familiarity with a brand, and that their perception of brand image directly affects ITP.

The results of Hypothesis 2 confirm that perceived quality is also positively related to ITP in a hotel restaurant dining context. The perceived brand quality component explained almost 15 per cent of the variance of ITP. These results indicate that perceived quality, including product and service quality, explains a significant proportion of the perceived quality aspects which relate to ITP. As previously mentioned, others have found the similar relationships, as highlighted by Caruana and Fenech [26], Chen and Quester [27] and Lai Lai [28]. The fundamental aspect of perceived quality is overall satisfaction, which includes product performance and reliable service. Importantly, these were seen to be embedded in the perception of perceived value in studies carried out by Swan [29] and McDougall [20], with each of these researchers noting that a consumer's satisfaction, and the aspects which meet their expectation, depend on product performance and service satisfaction. One crucial component of perceived value that leads to consumer ITP in hotel restaurant dining is when the consumer perceives quality which incorporates both the performance of the product and the overall service quality.

The results also support Hypotheses 3 and 4; perceived sacrifice, involving both monetary and non-monetary price, which is positively related to ITP hotel restaurant dining. The perceived sacrifice of both monetary and non-monetary explained, respectively, approximately 13 and 22 per cent of the variance in ITP respectively. The evaluation analysis indicates that the effect of attitude toward a brand name can clarify a significant proportion of perceived sacrifice as related to ITP. Based on the studies of Lai Lai [28] and Zeithaml [17] discussed previously, value is whatever the consumer expects in a product, and is a quality they receive for the price they pay. In this way pricing indicates the monetary sacrifice needed to purchase, and indicates the level of quality and perceived value. More specifically, Monroe [18] claims that the relationship between perceived value and ITP involves a cognitive trade-off between the benefit a consumer perceives in a product, and the sacrifice they perceive in needing to pay for it, both of a monetary and non-monetary [18] [21]. The previous findings of Grewal et al. [15] also found that a buyers' internal reference price is influenced by advertised selling prices; an internal reference price is a price in a buyer's memory which serves as a reference point for judging or comparing actual prices 
[15].

In terms of perceived sacrifice/monetary price in this study, a consumer's internal reference price is based on the comparison of the actual price or the price from previous experiences in similar restaurants. Consumers compare between features, such as ingredients used to make a meal, and reflect on the price and the value they receive which influences their ITP. Likewise, consumers also perceive sacrifice in terms of non-monetary price, such as a trade-off between time and energy waiting for a meal and service, influencing their ITP accordingly. In summary, this study has confirmed that perceived sacrifice influences ITP in a hotel restaurant dining context.

Concluding, this study has demonstrated the positive relationship between perceived value and ITP in a hotel restaurant dining context. Each of the three elements of perceived value: perceived brand image, perceived quality and perceived sacrifice (both monetary and non-monetary price) combines to explain over two-thirds (67 per cent) of the variance in ITP. The main two factors were perceived brand image and perceived sacrifice (non-monetary price), which each explained 20 per cent of the variance in ITP. The remaining factors, perceived quality and perceived sacrifice (monetary) explained 13 and 14 per cent of the variance, respectively. Hence, these four key factors are the decision making of consumers regarding ITP in the hotel restaurant dining context.

\section{Implications}

The key theoretical contribution of this study lies in its conceptualized model of perceived value. In this regard, the findings indicate that there are three main components to perceived value and ITP: perceived brand image, perceived quality and perceived sacrifice (monetary and non-monetary). In terms of perceived brand image, the findings of this study suggest that its role is the direct result of intrinsic cues. Within the literature, these cues comprise brand name, familiarity, popularity, a manufacturer's reputation and theme of the brand [14] [17]. The findings of this study suggest that the intrinsic cues depend on the consumer's attitude towards hotel restaurant dining, and more specifically, that the focus is on product perceptions including food, on a restaurant being a pleasant place for dining, and on good overall service.

The second component which links the perceived value construct with ITP is perceived quality. The results of this investigation again support the literature, in that a key index of perceived quality is derived from the extrinsic cues which include product and service performance, and which must be reliable [14].

The final component that links perceived value with ITP concerns perceived sacrifice. This component incorporates two distinct parts; firstly, perceived sacrifice in terms of monetary price, and secondly, perceived sacrifice in terms of non-monetary price. Both Monroe [18] and Patterson and Spreng [6] have asserted that price plays a vital role in determining perceived value as it represents the value of the goods. The findings of this study concur, and reveal that mone- 
tary and non-monetary price is indeed a predominant component when it comes to ITP. Dodds et al. [21] and Zeithaml [17] also asserted that the endeavor to obtain satisfaction from products and service involves sacrificing time and energy. Based on this study's findings, this hypothesis finds reasonable support; perceived sacrifice on a non-monetary price (for instance, time and energy) seems to be a heavily weighted variable when it comes to the relationship between perceived value and ITP.

\section{Conflicts of Interest}

The author declares no conflicts of interest regarding the publication of this paper.

\section{References}

[1] Rutherford, D.G. (2002) Hotel Management and Operations. 3rd Edition, John Wiley \& Sons, USA.

[2] Heung, V.C.S. and Lam, T. (2003) Customer Complaint Behavior towards Hotel Restaurant Services. International Journal of Contemporary Hospitality Management, 15, 283-289. https://doi.org/10.1108/09596110310482209

[3] Weiss, R., Feinstein, A.H. and Dalbor, M. (2004) Customer Satisfaction of Theme Restaurant Attributes and Their Influence on Return Intent. Journal of Foodservice Business Research, 7, 23-41. https://doi.org/10.1300/J369v07n01_03

[4] Liu, Y. and Jang, S.S. (2009) The Effects of Dining Atmospherics: An Extended Mehrabian-Russell Model. International Journal of Hospitality Management, 28, 494-503. https://doi.org/10.1016/j.ijhm.2009.01.002

[5] Olshavsky, R.W. (1985) Perceived Quality in Consumer Decision Making an Integrated Theoretical Perspective. In: Jacoby, J. and Olson, J.C., Eds., Perceived Quality, D.C. Heath, USA.

[6] Patterson, P.G. and Spreng, R.A. (1997) Modelling the Relationship between Perceived Value, Satisfaction and Repurchase Intentions in a Business-to-Business, Services Context: An Empirical Examination. International Journal of Service Industry Manager, 8, 414-434. https://doi.org/10.1108/09564239710189835

[7] Caruana, A. and Fenech, N. (2005) The Effect of Perceived Value and Overall Satisfaction on Loyalty: A Study among Dental Patients. Journal of Medical Marketing, 5, 245-255. https://doi.org/10.1057/palgrave.jmm.5040236

[8] Harcar, T., Kara, A. and Kucukemiroglu, O. (2006) Consumer's Perceived Value and Buying Behavior of Store Brands: An Empirical Investigation. The Business Review, 5, 55-62.

[9] Kashyap, R. and Bojanic, D.C. (2000) A Structural Analysis of Value, Quality, and Price Perception of Business and Leisure Travelers. Journal of Travel Research, 39, 45-51. https://doi.org/10.1177/004728750003900106

[10] Groth, J.C. (2001) Perceived Value and Psychological Thresholds: Implications for Marketing. Marketing Intelligence and Planning, 19, 145-152. https://doi.org/10.1108/02634500110391681

[11] Newman, J.W. (1957) New Insight, New Progress for Marketing. Harvard Business Review, 35, 95-102.

[12] Dobni, D. and Zinkhan, G.M. (1990) In Search of Brand Image: A Foundation Analysis. Advance in Consumer Research, 17, 110-119.

[13] Kirmani, A. and Zeithaml, V. (1993) Advertising, Perceived Quality, and Brand 
Image. In: Aaker, D.A. and Biel, A.L., Eds., Brand Equity \& Advertising: Advertising's Role in Building Strong Brands, Lawrence Erlbaum Associates, Hillsdale, NJ.

[14] Agarwal, S. and Teas, R.K. (2001) Perceived Value: Mediating Role of Perceived Risk. Journal of Marketing Theory and Practice, 9, 1-14. https://doi.org/10.1080/10696679.2001.11501899

[15] Grewal, D., Krishnan, R., Baker, J. and Borin, N. (1998) The Effect of Store Name, Brand Name and Price Discounts on Consumers' Evaluations and Purchase Intentions. Journal of Retailing, 74, 331-352. https://doi.org/10.1016/S0022-4359(99)80099-2

[16] Paswan, A.K., Spears, N. and Ganesh, G. (2007) The Effects of Obtaining One's Preferred Service Brand on Consumer Satisfaction and Brand Loyalty. Journal of Services Marketing, 21, 75-87. https://doi.org/10.1108/08876040710737840

[17] Zeithaml, V.A. (1988) Consumer Perceptions of Price, Quality, and Value: A Means-End Model and Synthesis of Evidence. Journal of Marketing, 52, 2-22. https://doi.org/10.1177/002224298805200302

[18] Monroe, K.B. and Krishnan, R. (1985) The Effect of Price on Subjective Product Evaluations. In: Jacoby, J. and Olson, J.C., Eds., Perceived Quality, D.C. Heath, USA, 209-232.

[19] Aaker, D.A. (1991) Managing Brand Equity: Capitalizing on the Value of a Brand Name. Maxwell Macmillan, New York.

[20] McDougall, G.H.G. (2000) Customer Satisfaction with Service: Putting Perceived Value into the Equation. Journal of Service Marketing, 14, 392-404. https://doi.org/10.1108/08876040010340937

[21] Dodds, W.B., Monroe, K.B. and Grewal, D. (1991) Effects of Price, Brand, and Store Information on Buyers' Product Evaluations. Journal of Marketing Research, 28, 307-319.

[22] Monroe, K.B. (1990) Pricing Making Profitable Decisions. 2nd Edition. McGraw-Hill Publishing Company, New York.

[23] Wells, W.D. (1961) Measuring Readiness to Buy. Harvard Business Review, 39, 81-87.

[24] Axelrod, J.N. (1968) Attitude Measure That Predict Purchase. Journal of Advertising Research, 8, 3-17.

[25] Simonin, B.L. and Ruth, J.A. (1998) Is a Company Known by the Company It Keeps? Assessing the Spillover Effects of Brand Alliances on Consumer Brand Attitudes. Journal of Marketing Research, 35, 30-42. https://doi.org/10.1177/002224379803500105

[26] Caruana, A. and Fenech, N. (2005) The Effect of Perceived Value and Overall Satisfaction on Loyalty: A Study among Dental Patients. Journal of Medical Marketing, 5, 245-255. https://doi.org/10.1057/palgrave.jmm.5040236

[27] Chen, S.C. and Quester, P.G. (2006) Modeling Store Loyalty: Perceived Value in Market Orientation Practice. Journal of Services Marketing, 20, 188-198. https://doi.org/10.1108/08876040610665643

[28] Lai Lai, T. (2004) Service Quality and Perceived Value's Impact on Satisfaction, Intention and Usage of Short Message Service (SMS). Information System Frontiers, 6, 353-368. https://doi.org/10.1023/B:ISFI.0000046377.32617.3d

[29] Swan, J.E. (1976) Product Performance and Consumer Satisfaction: A New Concept. Journal of Marketing, 40, 25-33. https://doi.org/10.2307/1251003 